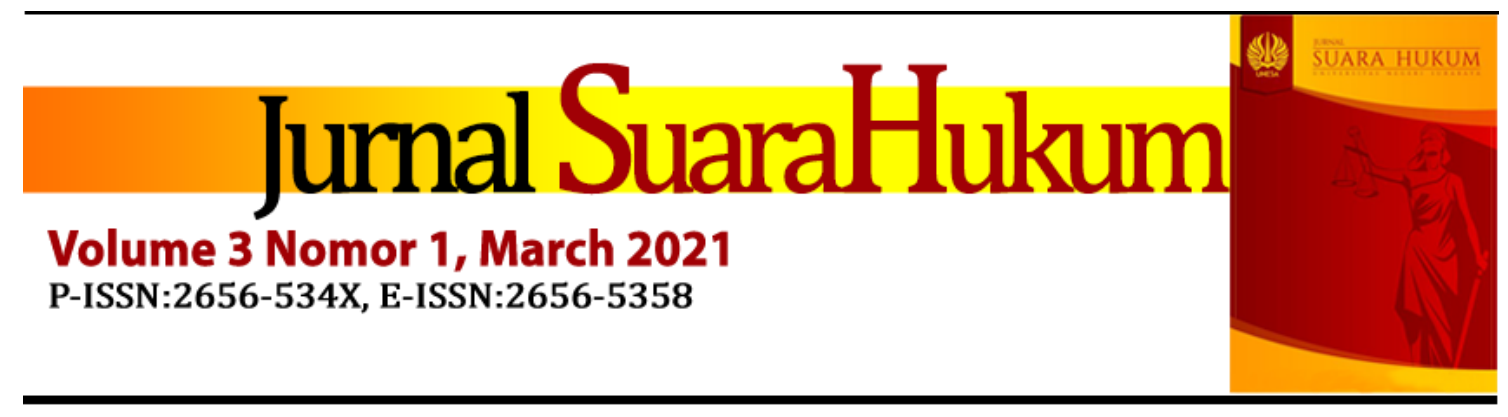

\title{
Implementasi Pengelolaan Kualitas Dan Pengendalian Pencemaran Air Di Home Industry Krupuk Desa Kenanga Sindang Indramayu
}

\author{
Nurwahyuni \\ Fakultas Hukum, Universitas Wiralodra, Indramayu, Indonesia, \\ nurwahyuni689@yahoo.com
}

Article history:

Received: 10 December 2020 | Last Revision: 13 February 2021 | Accepted: 20 February 2021

\begin{abstract}
The impact of modernization in the industrial sector has the potential to produce waste as residual products that can pollute the environment, damage and / or endanger health and the environment. Actualization of these threats is contrary to the ecologically Sustainable Development Principle which requires preservation of functions and controlling environmental pollution and damage. The disposal of waste from the production of krupuk Home Industry in Kenanga Village, Sindang Subdistrict, is channeled into a river which is a source of water for the community, causing river pollution. This research is a normative juridical research, based on normative analysis, legal science approach. Primary data as the main data is obtained from various legal materials related to research, supported also by secondary and tertiary data as additional data. The results showed that the implementation of Indramayu Regency Regional Regulation Number 9 of 2012 concerning Water Quality Management and Water Pollution Control, has not been implemented properly. This is evident from the existence of river pollution which is the source of water in Kenanga Village, Sindang Subdistrict, Indramayu Regency, which can no longer be used for people's daily lives due to the waste of krupuk production. The legal responsibility of cracker producers in the management of production waste as stipulated in Article 28 of Indramayu Regency Regulation Number 9 of 2012 concerning Water Quality Management and Water Pollution Control, which is subject to administrative sanctions in the form of a written warning, is deemed not to have a deterrent effect.
\end{abstract}

Keywords: Implementation, Local Regulation, River Pollution. 


\begin{abstract}
Abstrak
Dampak modernisasi sektor industri berpotensi menghasilkan limbah sebagai sisa hasil produksi yang dapat mencemarkan lingkungan, merusak dan/atau membahayakan kesehatan dan lingkungan hidup. Aktualisasi ancaman tersebut bertentangan dengan ecologically Sustainable Development Principle yang menghendaki kelestarian fungsi dan mengendalikan pencemaran dan kerusakan lingkungan hidup. Pembuangan limbah hasil produksi krupuk Home Industry Desa Kenanga Kecamatan Sindang dialirkan ke sungai yang menjadi sumber mata air masyarakat sehingga menimbulkan pencemaran sungai. Penelitian ini merupakan penelitian Yuridis Normatif, yang basisnya analisis normatif, pendekatan ilmu hukum, Data primer sebagai data utama diperoleh dari berbagai bahan hukum yang berhubungan dengan penelitian, didukung juga dengan data sekunder dan tersier sebagai data tambahan. Hasil penelitian menunjukan bahwa Implementasi Perda Kabupaten Indramayu Nomor 9 Tahun 2012 tentang Pengelolaan Kualitas Air dan Pengendalian Pencemaran Air, belum terlaksanakan dengan baik. Hal ini terbukti dari masih adanya pencemaran sungai yang menjadi sumber mata air Desa Kenanga Kecamatan Sindang Kabupaten Indramayu tidak lagi bisa digunakan untuk kehidupan sehari-hari masyarakat akibat limbah produksi krupuk. Tanggung Jawab Hukum produsen krupuk dalam pengelolaan limbah produksi sebagaimana diatur dalam Pasal 28 Perda Kabupaten Indramayu Nomor 9 Tahun 2012 tentang Pengelolaan Kualitas Air dan Pengendalian Pencemaran Air, yaitu dikenakan sanksi Administratif berupa teguran tertulis dirasa masih belum membuat efek jera.
\end{abstract}

Kata Kunci: Implementasi, Peraturan Daerah, Pencemaran Sungai.

\title{
A. PENDAHULUAN
}

Indonesia dikenal sebagai negara dengan perairan yang sangat luas, oleh karena itu penduduk Indonesia juga mempunyai tanggung jawab yang besar dalam rangka pelestarian fungsi air baik pemerintah maupun masyarakat pada umumnya, Undangundang Dasar Negara Republik Indonesia Tahun 1945 mengamanatkan dalam Pasal 33 ayat (3) yaitu: "bumi, air dan kekayaan alam yang terkandung di dalamnya dikuasai oleh Negara dengan tujuan untuk kesejahteraan masyarakat”. Air merupakan sumber 
daya alam yang memenuhi hajat hidup orang banyak sehingga perlu dilindungi agar dapat tetap bermanfaat bagi hidup dan kehidupan manusia serta mahluk hidup lainnya. Untuk menjaga atau mencapai kualitas air sehingga dapat dimanfaatkan secara berkelanjutan sesuai dengan tingkat mutu air yang diinginkan, maka perlu upaya pelestarian dan/atau pengendalian (Muchtar \& Naroida, 2016). Muhamad Naslilmuna mengemukakan bahwa air yang telah tercemar, baik oleh senyawa organik maupun anorganik akan mudah sekali menjadi media berkembangnya berbagai macam penyakit (Naslilmuna, 2018).

Seiring dengan pertumbuhan ekonomi dan penduduk, jenis dan kuantitas limbah akan menjadi pelik dan menjadi masalah besar di masa depan, hal tersebut terjadi karena ketidakpedulian pelaku ekonomi dan masyarakat terhadap kaidah pelestarian lingkungan, sosial budaya dan hukum (Yuda, 2018). Modernisasi di sektor industri telah mendatangkan manfaat positif seperti: semakin terbukanya lapangan pekerjaan, meningkatnya pendapatan masyarakat dan lain sebagainya. Namun di sisi lain ternyata modernisasi di sektor industri membawa dampak negatif terutama terhadap lingkungan hidup yang dengan maraknya pencemaran dan perusakan lingkungan hidup yang dilakukan oleh perusahaan-perusahaan.

Masalah lingkungan hidup merupakan masalah alami, yakni peristiwa-peristiwa yang terjadi sebagai bagian dari proses natural. Proses natural ini terjadi tanpa menimbulkan akibat yang berarti bagi tata lingkungan itu sendiri dan dapat pulih kemudian secara alami (homeostasi). Akan tetapi, sekarang masalah lingkungan tidak lagi dapat dikatakan sebagai masalah yang semata-mata bersifat alami, karena manusia memberikan faktor penyebab yang sangat signifikan secara variabel bagi peristiwaperistiwa lingkungan (Herlina, 2015). 
Salah satunya dampak negatif dari sektor industri terjadinya pencemaran limbah pada sungai dalam suatu lingkungan masyarakat di Desa Kenanga Kabupaten Indramayu akibat industri krupuk hal ini terbukti dari adanya pelaksana teknis badan lingkungan hidup Kabupaten Indramayu melakukan pengukuran kualitas sungai setiap tahun. Dari delapan sungai yang status mutu airnya tercemar sedang, terdapat dua yang indeks pencemarannya paling tinggi yakni saluran Kenanga/Dukuh Kerupuk dengan nilai indeks pencemaran (IP) mencapai 6,913 dan Kali Prajagumiwang dengan IP 6,859. Saluran aliran Kenanga/Dukuh Kerupuk, kondisi pencemaran di antaranya disebabkan oleh kadar BOD yang tinggi hingga 12,8 (baku mutu 6), deterjen 1,5 (baku mutu 0,2), fenol 0,05 (baku mutu 0,001), kromium 0,09 (baku mutu 0,05) dan sulfida 0,1 (baku mutu 0,002). Selain itu, tembaga 0,14 (baku mutu 0,02), timbal 1,2 (baku mutu 0,03), dan E Coli 3,9X103 (baku mutu 2.000). Sedangkan Kali Prajagumiwang, kadar BOD mencapai 105 (baku mutu 6), COD 303,11 (baku mutu 50), deterjen 0,92 (baku mutu 0,2), fenol 0,35 (baku mutu 0,001), nitrat 25,76 (baku mutu 20) dan timbal 0,55 (baku mutu 0,03).

Enam sungai lainnya yang berstatus tercemar sedang, IP-nya masing-masing Sungai Cimanuk Lama (setelah waduk Bojongsari/Jembatan RSUD) sebesar 6,440 dan sungai Cimanuk Lama (Waduk Bojongsari, Sekitar Intake PDAM) sebesar 6,152. selain itu, Sungai Cimanuk Lama Sekitar Sentra Pengrajin Batik Paoman (IP up stream 6,11dan IP down stream 5,624). serta sungai cimanuk sekitar bendung bangkir dengan IP 6,242 (sebelum bendung bangkir) dan 5,268 (sesudah bendung bangkir) serta sungai cimanuk (jatibarang) dengan IP 6,199. Kualitas air sungai dipengaruhi oleh kualitas pasokan air yang berasal dari daerah tangkapan sedangkan kualitas pasokan air dari 
daerah tangkapan berkaitan dengan aktivitas manusia yang ada di dalamnya (Arnop, 2019).

Mengelola lingkungan hidup sebagaimana yang diatur dalam Undang-Undang Nomor 32 Tahun 2009 tentang Perlindungan dan Pengelolaan Lingkungan Hidup (PPLH). Hal tersebut dilakukan dan ditujukan untuk melindungi lingkungan hidup dari pelaku kejahatan yang dilakukan oleh orang atau sekelompok orang yang dengan sengaja merusak lingkungan kita yang akan berimplikasi atau berdampak terhadap kelangsungan kehidupan masyarakat.

Undang-undang Nomor 36 Tahun 2009 tentang Kesehatan pada Pasal 162 merumuskan bahwa kualitas lingkungan yang sehat ditunjukan untuk mewujudkan kualitas lingkungan yang sehat, baik fisik,kimia,biologi maupun sosial guna mencapai derajat kesehatan lingkungan yang setinggi-tingginya. Lingkungan hidup dalam jurnal Hapsari Wahyuningsih menyebutkan bahwa Lingkungan Hidup untuk mendukung kehidupan mahluk hidup yang ada di dalamnya seringkali disebut sebagai daya dukung. Dalam Undang-Undang Lingkungan Hidup, daya dukung lingkungan adalah kemampuan suatu lingkungan untuk mendukung peri kehidupan manusia dan makhluk hidup lainnya (Wahyuningsih, 2018).

Pemerintah Daerah telah menetapkan Peraturan Daerah Kabupaten Indramayu Nomor 9 Tahun 2012 Tentang Pengelolaan kualitas Air dan Pengendalian Pencemaran Air untuk menjaga kualitas air di kabupaten Indramayu, tapi nyatanya belum dilakukan secara maksimal. Hal ini dapat dilihat dari nilai masih adanya pencemaran limbah yang ada di sungai desa kenanga, hal itu dibuktikan dengan IP yang menunjukan adanya pencemaran pada saluran Kenanga/Dukuh Kerupuk dengan nilai indeks pencemaran (IP) mencapai 6,913. Kurangnya ketegasan dalam penegakan hukum terhadap 
pencemaran lingkungan yang dilakukan oleh produsen krupuk Home Industry yang seharusnya di optimalkan demi menjaga kelestarian lingkungan.

Dari uraian diatas, oleh karenanya penulis tertarik untuk melakukan penelitian dengan judul "Implementasi Pengelolaan Kualitas Dan Pengendalian Pencemaran Air di Home Industry Krupuk Desa Kenanga Sindang Indramayu”. Dengan demikian, maka pertanyaan atau identifikasi masalah penelitian yang diajukan dalam penelitian ini adalah :

1. Bagaimana Implementasi Perda Kabupaten Indramayu Nomor 9 Tahun 2012 Tentang Pengelolaan Kualitas Air dan Pengendalian Pencemaran Air terhadap Pencemaran Sungai Oleh Limbah Akibat Industri Krupuk Di Desa Kenanga Kecamatan Sindang Kabupaten Indramayu?

2. Bagaimana Penerpan Sanksi Hukum bagi Produsen Krupuk Home Industry Krupuk Desa Kenanga Kecamatan Sindang Kabupaten Indramayu dalam pencemaran Sungai?

\section{B. METODE PENELITIAN}

Pendekatan penelitian yang digunakan adalah pendekatan yuridis-normatif yang dilakukan berdasarkan bahan hukum utama dengan cara menelaah teori-teori, konsepkonsep, asas-asas hukum serta peraturan perundang-undangan yang berhubungan dengan penelitian ini. Pendekatan ini dikenal pula dengan pendekatan kepustakaan serta kajian implentasi di masayarakat, bahan hukum tersier yang akan digunakan penulis dalam penelitian ini menggunakan kamus, ensklopedia, dan sejenisnya untuk memperjelas bahan hukum primer dan sekunder. 


\section{HASIL DAN PEMBAHASAN}

1. Implementasi Perda Kabupaten Indramayu Nomor 9 Tahun 2012 Terhadap Pencemaran Sungai Oleh Limbah Akibat Industri Krupuk Di Desa Kenanga Kecamatan Sindang Kabupaten Indramayu.

Air merupakan sumber daya alam yang memenuhi hajat hidup orang banyak sehingga perlu dilindungi agar dapat tetap bermanfaat bagi hidup dan kehidupan manusia serta mahluk hidup lainnya. Untuk menjaga atau mencapai kualitas air sehingga dapat dimanfaatkan secara berkelanjutan sesuai dengan tingkat mutu air yang diinginkan, maka perlu upaya pelestarian dan/atau pengendalian.

Pelestarian kualitas air merupakan upaya untuk memelihara fungsi air agar kualitasnya masih tetap pada kondisi alamiahnya. Air sebagai komponen lingkungan hidup akan mempengaruhi dan dipengaruhi oleh komponen lainnya. Penurunan kualitas air akan menurunkan daya guna, hasil guna, produktivitas, daya dukung dan daya tamping dari sumber daya pada akhirnya akan menurunkan kekayaan sumber daya alam. Penurunan kualitas air dapat diindikasikan dengan adanya peningkatan kadar parameter fisika (Walid, 2020). Air sebagai komponen sumber daya alam yang sangat penting maka harus dipergunakan untuk sebesar-besarnya bagi kemakmuran rakyat.

Penegakan hukum lingkungan merupakan suatu hal yang patut dilakukan oleh pemerintah untuk mengatasi masalah lingkungan hidup dalam rangka perlindungan terhadap lingkungan hidup. Upaya tersebut penting dilakukan melalui penegakan hukum untuk mencegah dan menanggulangi pencemaran dan kerusakan lingkungan, baik disebabkan 
oleh masyarakat maupun pelaku usaha. Perlindungan hukum terhadap lingkungan hidup harus didukung pula oleh instrumen hukum yang baik, peraturan perundang-undangan maupun instrumen hukumnya, serta didukung pula oleh peningkatan kesadaran hukum masyarakat (Soekanto, 1983).

Dalam penegakan hukum lingkungan harus diperhatikan, namun demikian hukum tidak identik dengan keadilan, Karena hukum itu sifatnya umum, mengikat semua orang, dan menyamaratakan. Dalam penataan dan penegakan hukum lingkungan, unsur kepastian, unsur kemanfaatan ,dan unsur keadilan harus dikompromikan, ketiganya harus mendapat perhatian secara proporsional. Sehingga lingkungan yang tercemar dapat dipulihkan kembali (Pratama, 2020).

Perangkat aturan sebagai aspek fundamental yang melandasi upaya pelestarian fungsi lingkungan hidup yang dapat digunakan sebagai upaya preventif terhadap pencemaran dan kerusakan lingkungan hidup adalah regulasi pengelolaan lingkungan hidup melalui, Undang-undang Nomor 23 Tahun 1997 Jo Undang-undang Nomor 32 Tahun 2009 Tentang Pengelolaan Lingkungan Hidup (UUPLH), pengaturan mengenai Analisis Dampak Lingkungan Hidup (AMDAL) yang saat ini telah dikemas dalam mekanisme perijinan berdasarkan Peraturan Pemerintah Nomor 27 Tahun 2012 Tentang Ijin Lingkungan Hidup, pengaturan di tingkat daerah sebagai pengaturan pelaksana dari (UUPLH) yaitu Perda Kabupaten Indramayu Nomor 9 Tahun 2012 tentang Pengelolaan Kualitas Air dan Pengendalian Pencemaran Air merupakan salah satu bentuk instrumen perlindungan 
kualitas air agar tetap bersih dan dapat di nikmati oleh hajat hidup orang banyak.

Hal ini berarti bahwa penggunaan air untuk berbagai manfaat dan kepentingan harus dilakukan secara bijaksana dengan memperhitungkan kepentingan generasi masa kini dan masa depan. Untuk itu air perlu dikelola agar tersedia dalam jumlah yang aman, baik kuantitas maupun kualitasnya, dan bermanfaat bagi kehidupan dan perikehidupan manusia serta mahluk hidup lainnya agar tetap berfungsi secara ekologis, guna menunjang pembangunan yang berkelanjutan. Lebih lanjut mengenai pengertian pencemaran air diatur dalam Pasal 1 ayat (11) Peraturan Pemerintah No. 82 Tahun 2001 tentang Pengelolaan Kualitas Air dan Pengendalian Pencemaran Air yaitu:

"Pencemaran air ialah masuknya atau dimasukkannya makhluk hidup, zat, energi dan atau komponen lain ke dalam air oleh kegiatan manusia, sehingga kualitas air turun sampai ke tingkat tertentu yang menyebabkan air tidak dapat berfungsi sesuai dengan peruntukannya”

Tujuan pengelolaan kualitas air ialah untuk menjamin kualitas air yang diinginkan pengelolaan kualitas air adalah untuk menjamin kualitas air yang diinginkan sesuai dengan peruntukannya, sedangkan tujuan pengendalian air adalah untuk menjamin kualitas air agar sesuai dengan baku mutu air melalui upaya pencegahan dan penanggulangan pencemaran air serta pemulihan kualitas air. Perda Kabupaten Indramayu Nomor 9 Tahun 2012 tentang Pengelolaan Kualitas Air dan Pengendalian Pencemaran Air merupakan salah satu bentuk 
instrumen perlindungan kualitas air agar tetap bersih dan dapat di nikmati oleh hajat hidup orang banyak.

Berdasarkan data dari Badan Lingkungan Hidup (BLH) Kabupaten Indramayu terdapat sepuluh sungai yang ada di Kabupaten Indramayu tercemar limbah, sepuluh sungai itu antara lain, Kali Ceblok, Kali Prajagumiwang, saluran Desa Kenanga/Dukuh Kerupuk, Sungai Cimanuk Lama setelah Waduk Bojongsari/jembatan RSUD, Sungai Cimanuk Lama Waduk Bojongsari, sekitar intake PDAM, Sungai Cimanuk Lama sekitar sentra pengrajin batik Paoman up stream dan down stream, dan Sungai Cimanuk Lama sekitar sentra pabrik kerupuk Kenanga up stream dan down stream. Kemudian sungai Cimanuk sekitar Bendung Bangkir, sungai Cimanuk (Jatibarang) dan muara Kali Prajagumiwang. Namun hanya terdapat dua yang statusnya tercemar ringan yaitu Kali Ceblok dan sungai Cimanuk Lama sekitar sentra pabrik kerupuk Desa Kenanga Kecamatan Sindang up stream dan down stream dan siasanya berstatus tercemar sedang.

Salah satu sumber mata air di Desa Kenanga Kecamatan Sindang Kabupaten Indramayu adalah Sungai Besar Cimanuk dan Saluran Kenanga/Dukuh Kerupuk dengan nilai indeks pencemaran (IP) mencapai 6,913, kedua Mata air tersebut sudah tercemari oleh Limbah akibat produksi krupuk yang dilakukan oleh produsen krupuk. Jumlah aliran air limbah yang berasal dari industri sangat bervariasi tergantung dari jenis dan besar kecilnya industri, pengawasan industri, derajat penggunaan air, derajat pengolahan air limbah yang ada. Air limbah mempunyai komposisi yang sangat bervariasi sesuai dengan sumber asalnya. Polutan dalam air mencakup unsur-unsur kimia, pathogen/bakteri dan perubahan sifat Fisika dan kimia dari air. Banyak unsur-unsur kimia merupakan racun yang 
mencemari air. Patogen/bakteri mengakibatkan pencemaran air sehingga menimbulkan penyakit pada manusia dan binatang. Adapuan sifat fisika dan kimia air meliputi derajat keasaman, konduktivitas listrik, suhu dan pertilisasi permukaan air (Belladona, 2017).

Self purification merupakan suatu proses alami dimana sungai mempertahankan kondisi asalnya melawan bahan-bahan asing yang masuk ke dalam sungai. Pencemaran air yang relatif berat akan menyebabkan air tidak mampu untuk membersihkan diri secara alami (Nur Majid Nafiadi:2013). Kualitas air sungai dipengaruhi oleh tata guna lahan. Kemampuan daya tampung air sungai secara alamiah terhadap pencemaran harus tetap dipertahankan untuk meminimalkan terjadinya penurunan kualitas air sungai. Kualitas air dapat diketahui dengan melakukan pengujian di laboratorium. Pengujian kualitas air dilakukan dengan menguji parameter fisik, kimia, dan biologi seperti bau dan warna. Parameter kualitas air terdiri dari parameter fisika yaitu suhu, kekeruhan, dan sebagainya), parameter kimia terdiri dari $\mathrm{COD}, \mathrm{BOD}, \mathrm{pH}, \mathrm{DO}$ dan sebagainya, dan parameter biologi seperti keberadaan bakteri dan sebagainya.

Partikel senyawa organik yang berasal dari kegiatan domestik manusia dapat ditemukan sebagai partikel koloid dan kasar yang dapat menyebabkan cahaya terhalang masuk kedalam air sehingga menyebabkan kekeruhan menjadi tinggi. Nilai $\mathrm{pH}$ yang rendah mengindikasikan bahwa terjadinya penurunan kualitas perairan yang nantinya berdampak terhadap kehidupan biota air. Akibat dari perubahan ini akan membunuh biota yang paling toleran sekalipun, hal ini dikarenakan jaringan makanan pada perairan terganggu. Selain perubahan $\mathrm{pH}$, konsentrasi oksigen terlarut yang berubah juga dapat mengindikasikan terjadinya 
perubahan kualitas air dimana semakin rendah konsentrasi oksigen terlarut maka semakin rendah kualitas perairan. Lingkungan dapat tercemar jika dimasuki atau kemasukan bahan pencemar yang dapat mengakibatkan gangguan pada makhluk hidup yang ada di dalamnya. Menurunnya kualitas air ditandai dengan perubahan warna air dan bau.

Berdasarkan data Disperindag Kabupaten Indramayu Terdapat 38 unit usaha pengrajin krupuk yang dapat di klasifikasikan menjadi dua golongan yaitu, Industri skala kecil dan Industrii skala menengah /sedang. Jumlah Industri kecil sebanyak 30 Unit usaha sedangkan industri unit menengah sebanyak 8 unit usaha. Salah satu contoh pabrik krupuk di Desa Kenanga Kecamatan Sindang Kabupaten Indramayu adalah: Pabrik Krupuk Wirajaya yang terletak di Desa Kenanga, pabrik ini di dirikan oleh Ibu Kholini selaku pemilik pabrik Wira Jaya, baprik ini memproduksi banyak jenis krupuk diantaranya, kerupuk ikan, kerupuk udang, kerupuk jengkol dan lain sebagainya. Ibu kholini memiliki 15 orang karyawan, dengan sistem kerja dimulai dari pkl. 07.00-17.00 WIB. Pengelolaan limbah pada pabrik ini hanya terdapat satu mesin perebus hasil bahan makanan, setelah itu hasil dari pengolahan krupuk langsung di buang ke sungai yang terdapat di belakang industri krupuk tersebut.

Pencemaran limbah krupuk merupakan salah satu penyebab kerusakan lingkungan hidup dan dapat menyebabkan penyakit kepada umat manusia. Para industri selalu melakukan apapun untuk mendapatkan keuntungan yang besar untuk kepentingan diri mereka sendiri, Krupuk merupakan makanan ringan dan mudah untuk di dapatkan. Sedangkan pengertian limbah menurut Ilyas limbah adalah "bahan yang terbuang dari hasil aktivitas manusia. Maka limbah dapat 
diterjemahkan secara sederhana adalah suatu bahan yang terbuang dari sumber hasil aktivitas manusia maupun alam yang belum mempunyai nilai ekonomi” (Ilyas, 2018).

Pengendalian dampak lingkungan hidup mencakup tiga aspek penting, yaitu pencegahan, penanggulangan dan pemulihan. Diantara ketiga aspek pengendalian ini, pencegahan dampak lingkungan hidup mendapat porsi pengaturan yang paling banyak. Ada banyak sekali instrumen pencegahan yang di akomodasi dan di atur dalam undang - undang (Keraf, 2010). Pelaksanaan pengendalian dampak lingkungan hidup dilakukan dengan didasarkan pada perencanaan perlindungan dan pengelolaan lingkungan hidup yang mencakup inventarisasi ligkungan hidup, penetapan wilayah ekoregian, dan RPPLH (rencana perlindungan dan pengelolaan lingkungan hidup) yang perlu diatur lebih lanjut di dalam peraturan pemerintah (PP) dan Peraturan Daerah (Perda) untuk menjamin efektifitas implementasinya.

\section{Pasal 18 Undang-Undang Dasar 1945 menegasakan bahwasanya} mengartikan sebuah Implementasi pelaksanaan pemerintahan daerah yang ditegaskan dalam Pasal 18 UUD 1945, akan sangat berpotensi timbulnya kemungkinan berkembangnya pluralism dan penegakan di daerah guna menyelamatkan asset di daerah. Oleh karena itu, dalam pelaksanaan pemerintahan daerah berdasarkan Undang-undang No 23 Tahun 2014 tentang Pemerintahan Daerah, diperlukan antisipatif pemikiran sinkronisasi hukum terhadap berbagai kemungkinan timbulnya keanekaragaman dalam sistem materi muatan Peraturan Daerah. Dalam proses pembentukan Peraturan Daerah Provinsi, Peraturan Daerah Kabupaten/Kota (Santosa, 1997). Implementasi ini memberikan dan menegasakan fungsi dari undang-undang itu untuk di implentasikan di daerah karena Indonesia 
mengakui untuk otonomi daerah dalam pasal 18 UUD 1945, demikian pula memeberikan suatu kewenangan kepada daerah dalam hal ini daerah Indramayu yang dimana daerah mempunyai peraturan daerah yang bersangkutan guna melindungi, mengelola dan memahami serta mengembangkan daerah dan potensi di daerah tersebut.

Peraturan daerah memiliki beberapa fungsi, seperti sebagai instrumen kebijakan dan monitoring serta evaluasi untuk melaksanakan otonomi daerah dan tugas pembantuan sebagaimana amanat Undang-Undang Dasar Republik Indonesia Tahun 1945 dan Undang-Undang tentang Pemerintahan Daerah. Kemudian, fungsi yang kedua sebagai penampung kekhususan dan keragaman daerah, serta penyalur aspirasi masyarakat di daerah. Undang-undang Nomor 32 Tahun 2009 tentang Perlindungan dan Pengelolaan Lingkungan Hidup merupakan suatu bentuk implementasi kebijakan pemerintah dalam mengupayakan perlindungan terhadap lingkungan hidup, dari adanya Undang-undang Nomor 32 Tahun 2009 tersebut, maka pemerintah daerah melakukan implementasi Undangundang dengan dibuatnya Peraturan Pemerrintah Nomor 82 Tahun 2001 Tentang Pengendalian Pencemaran Air dan dibuatnya Perda Kabupaten Indramayu Nomor 9 Tahun 2012 tentang Pengelolaan Kualitas Air dan Pengendalian Pencemaran Air .

Lingkungan hidup yang baik dan sehat merupakan hak asasi setiap warga Negara Indonesia sebagaimana dimanatkan dalam Pasal 28H Undang-undang Dasar Negara Kesatuan Republik Indonesia 1945. Perlindungan lingkungan hidup merupakan suatu masalah yang harus dipertimbangkan dari aspek global. Limbah industri hendaknya dibuang pada wadah yang telah di sediakan. Masyarakat di 
sekitar sungai perlu memperhatikan kebersihan lingkungan dan perlu memahami mengenai pemanfaatan sungai, agar sungai tidak lagi dipergunakan sebagai tempat pembuangan limbah. Peraturan pembuangan limbah industri hendaknya dipantau pelaksanaannya dan pelanggarnya dijatuhi hukuman.

Limbah industri hendaknya diproses dahulu dengan teknik pengolahan limbah, dan setelah memenuhi syarat baku mutu air buangan baru bisa dialirkan ke selokan-selokan atau sungai. Dengan demikian akan tercipta sungai yang bersih dan memiliki fungsi ekologis. Tindakan yang perlu dilakukan oleh masyarakat yaitu; pembuatan kolam pengolah limbah cair. Baku mutu limbah cair ditetapkan oleh Menteri yang membidangi lingkungan hidup. Menteri lain dan pimpinan lembaga pemerinah non-departemen, untuk melindungi kualitas air, Gubernur setelah bekonsultasi dengan Menteri dapat menetapkan baku mutu limbah cair lebih hebat dari baku mutu limbah cair yang ditetapkan Menteri (Muhamat, 2008).

Seharusnya dalam pengolahan air limbah harus melalui beberapa proses diantaranya adalah:

1. Proses pengolahan kombinasi kimia dan fisik;

2. Proses pengolahan kombinasi biologi dan fisik.

Dalam pembangunan dan oprasional instalasi pengolahan air limbah , beberapa hal yang perlu dipertimbangkan:

1. Kualitas air limbah yang ada;

2. Proses pengolahan yang dipilih;

3. Teknologi yang akan di aplikasikan;

4. Biaya investasi dan oprasional; 
P-ISSN: 2656-534X, E-ISSN: 2656-5358

Jurnal Suara Hukum, Vol. 3, No. 1, Maret 2021

5. Ketersediaan lahan;

6. Ketersediaan Sumber Daya Menusia (SDM).

Pengolahan air limbah dapat dilakukan melalui beberapa tahapan diantaranya adalah:

1. Bak Kontrol (Penampung Air Limbah)

Air limbah yang berasal dari pencucian udang, ikan, jengkol dan lainnya, dialurkan melalui saluran air limbah menuju ke Bak Penampung Air Limbah bak ini bertujuan untuk menampung sementara air limbah, homogenasi air limbah. Air limbah darii Bak Penampung di pompa menuju Bak Screen.

2. Bak Screen

Bak Screen merupakan salah satu bak yang berisi Screen yang berfungsi untuk memisahkan padatan yang terdapat dalam air limbah. Setelah mengalami proses pemisahan padatan selanjutnya di pompa menuju Bak Equalisasi.

3. Bak Equalisasi

Bak ini merupakan proses awal pengolahan air limbah, pada bak ini dapat berisi mikroorganisme maupun tidak Bak ini bertujuan untuk memproses pengolahan air limbah awal, pada bak ini di injeksikan udara di dalamnya agar air yang di hasilkan tidak berbau, udara yang di injeksikan bersumber dari blower atau sumber lainnya. Pada bak ini dibutuhkan pengontrolan untuk mengukur kesaman $(\mathrm{Ph})$, dengan injeksi udara dapat menurunkan konsentrasi COD dan BOD kurang lebih 10-30\%, 
hal ini tergantung waktu tinggal air limbah pada bk equalisasi, air limbah selanjutnya di alirkan ke Bak Kontak.

\section{Bak Kontak}

Bak ini merupakan proses utama, pada bak ini diisikan mikroorganisme dan injeksi udara yang mengakibatkan terjadinya penguraian bahan penecemar menjadi bahan yang lebih sederhana dan tidak berbahaya dan gas. Gas yang dihasilkan biasanya terbuang langsung ke lingkungan. pada bak ini terjadi penurunan konsentrasi COD dan BOD kurang lebih 90-95\% Selanjutnya air di alirkan menuju Bak Pemisah Mikroorganisme (pengendapan/clarifier).

5. Bak Pemisah Mikrorganisme (pengendapan)

Pada baki ini mikroorganisme akan di endapkan dan di keluarkan menuju bak penampung, selanjutnya mikroorganisme di pompa di alirkan menuju bak stabilisasi, sedangkan air bersihnya akan keluar dari bagian atas dan selanjutnya di alirkan menuju bak karbon aktif selanjutnya air hasil pengolahan ini dapat di manfaatkan untuk pemeliharaan tanaman atau dibuang langsung ke sungai.

6. Bak Penampung

Bak ini merupakan tempat penampung dari Bak Pemisah, pada bak ini terjadi peningkatan konsentrasi mikroorganisme pada bak ini sebagian besar hampir 90\% selanjutkan dialirkan kembali menuju ke Bak Stabilisasi dan sisanya dapat dipergunakan untuk memelihara ikan sebagai sumber makanan.

7. Bak Stabilisasi 
Bak ini mikroorganisme di stabilkan dengan cara menginjeksikan udara kedalam bak stabilisasi, mikroorganisme yang telah mengalami proses stabilisasi ini selanjutnya dialirkan kembali ke Bak Kontak untuk proses utama pengolahan air limbah, proses ini berlangsung secara kontinyu 24 Jam.

Air limbah pada industri krupuk bersumber dari proses pencucian udang,ikan, jengkol, proses produksi dan pencucian lantai kerja, berdasarkan analisis laboratorium diketahui kualitas air limbah: 1) COD :335 mg/L, 2) BOD : $195 \mathrm{mg} / \mathrm{L}$, 3) $\mathrm{Ph}: 5,95$. Kesadaran lingkungan hidup yang baik dan sehat mengubah berbagai negara untuk melakukan penanganan. Kemampuan yang ditunjukan tidak lagi terbatas pada kondisi lokal atau batas wilayah, namun menggelobal. PPB melakukan konferensi untuk meninjaun hasil-hasil pembangunan dunia selama dasawarsa 1960-1970.

Masyarakat di sekitar sungai perlu memperhatikan kebersihan lingkungan dan perlu memahami mengenai pemanfaatan sungai agar sungai tidak lagi dipergunakan sebagai tempat pembuangan limbah. Peraturan pembuangan limbah industri hendaknya dipantau pelaksanaannya dan pelanggarnya dijatuhi hukuman. Kesadaran lingkungan hidup pada produsen krupuk desa Kenanga Kab. Indramayu juga perlu di terapkan mengingat adanya pencemaran limbah pada sungai Desa Kenanga yang di akibatkan oleh pembuangan limbah hasi produksi, Pencemaran limbah sangat berbahaya bagi biota di perairan berbagai jenis ekosistem mengalami keracunan. Semua kejadian pemcemaran yang terjadi terhadap lingkungan hidup pasti akan berdampak pada ekosistem (perairan dan laut), karena limbah cair industri krupuk menyebabkan kerusakan lingkungan, dan juga bisa berdampak pada kesehatan manusia. 
Adapun kebijakan pemerintah Daerah Kabupaten Indramayu dalam menetapkan Perda Kabupaten Indramayu tentang Kualitas Air bertujuan untuk melindungi sungai dari pencemaran, akan tetapi Implementasi dari Perda tersebut tidak sesuai dengan tujuan dari pembuatan perda tersebut di karenakan, beberapa faktor. Lawrence M. Friedman mengemukakan bahwa berfungsinya hukum dalam mengatasi berbagai permasalahan dalam masyarakat mencakup 3 (tiga) unsur yaitu (Friedman, 1975):

1. Substansi Hukum (Legal Substance) adalah peraturan-peraturan yang terdiri dari peraturan substantif dan peraturan-peraturan tentang bagaimana institusi-institusi harus bertindak. Peraturan-peraturan primer adalah. Norma, tingkah laku, sedangkan peraturan sekunder mengatur bagaimana norma-norma pokok dilaksanakan.

2. Struktur Hukum (Legal Structure) adalah pola yang memperlihatkan bagaimana hukum bekerja dengan bentuk yang tetap sebagai suatu sistem badan, jika kita menggambarkan struktur sebuah pengadilan maka pembicaraan tentang jumlah hakim, jurisdiksi pengadilan, bagaimana pengadilan yang lebih tinggi menangani pengadilan yang lebih rendah, dan apa peran mereka.

3. Budaya Hukum (Legal Culture) adalah sikap-sikap yang terpola, nilai-nilai, prinsip-prinsip, gagasan atau pendapat yang terstruktur sedemikian rupa sehingga dianut oleh setiap pribadi pada level individu dan kelompok didalam masyarakat. Secara substansial budaya hukum sifatnya lebih operasional dan dapat dinikmati melalui cara berbuat dan berfikir.

Pelaksanaan Perda Kabupaten Indramayu tidak memberikan pengaruh terhadap pengelolaan lingkungan hidup dikarenakan beberapa faktor diantanya, faktor budaya hukum masyarakat khsususnya produsen krupuk dalam perbuatan dan cara berfikir yang 
hanya menguntungkan pribadi tanpa memikirkan dampak dari pencemaran limbah yang dilakukan, faktor penegakan hukum pemerintah daerah yang tidak menerapkan sanksi kepada pelaku pencemaran baik sanksi teguran maupun sanksi administratif. Satjipto Raharjo mengemukakan bahwa hukum melindungi kepentingan seseorang dengan cara terukur (tertentu dan dalamnya) untuk bertindak dalam rangka kepentingan tersebut (Rahardjo, 1991). Senada juga, Salmond berkata bahwa perlindungan hukum bertujuan mengintegrasikan dan mengkoordinasikan berbagai kepentingan dalam masyarakat karena dalam lalu lintas kepentingan perlindungan terhadap kepentingan tertentu hanya dapat dilakukan dengan cara membatasi kepentingan dilain pihak.

Kepentingan hukum merupakan mengurusi hak dan kepentingan manusia sehingga hukum memiliki otoritas tertinggi untuk menentukan kepentingan manusia yang perlu diatur dan dilindungi. Perlindungan lingkungan hidup merupakan upaya untuk mencegah dan menanggulangi pencemaran dan kerusakan lingkungan hidup baik disebabkan oleh perbuatan manusia, hewan, proses alam, maupun hama penyakit. Upaya ini dimaksudkan untuk mempertahankan dan menjaga hak-hak negara, masyarakat dan perseorangan atas lingkungan hidup yang baik dan sehat.

\section{Penerapan Sanksi Hukum bagi Produsen Krupuk Home Industry Krupuk}

\section{Desa Kenanga Kecamatan Sindang Kabupaten Indramayu dalam} pencemaran Sungai

Permasalahan limbah merupakan salah satu masalah lingkungan hidup sampai saat ini belum dapat di tangani dengan baik, terutama di kota-kota besar. Hal ini di sebabkan karena dalam praktiknya pelaksanaan konsep ini menimbulkan banyak kendala. Masalah utama yang dihadapi adalah penataan dan 
penegakan hukum, masalah pembiayaan serta masih rendahnya tingkat kesadaran pengelolaan limbah, khususnya bagi industri yang berskala kecil dan menengah. Permasalahan inilah yang menyebabkan terjadinya pencemaran dan perusakan lingkungan yang kondisinya akan semakin parah bila dibarengi dengan lemahnya penegakan hukum. Konsentrasi pemerintah kebijakan pemerintah dalam pembangunan pelestarian lingkungan merupakan salah satu kebijaksanaan nasional di bidang lingkungan hidup yang menjadi perhatian pemerintah dalam aktivitas pembangunan nasional atas dasar pembangunan berkelanjutan untuk kesejahteraan masyarakat serta keadilan dengan keseimbangan pertumbuhan ekonomi, dinamisme sosial dan pelestarian fungsi lingkungan hidup.

Kegiatan pembangunan yang semakin meningkat sebagai upaya peningkatan kesejahteraan hidup selalu mengandung resiko pencemaran dan kerusakan lingkungan hidup, sehingga struktur dan fungsi dasar ekosistem yang menjadi penunjang kehidupan dapat rusak, oleh karena itu penggunaan sumberdaya alam harus selaras, serasi dan seimbang dengan fungsi lingkungan hidup (Azwar, 1990). Dalam hal ini undang-undang berkehendak bahwa "setiap orang berkewajiban memelihara kelestarian fungsi lingkungan hidup serta mencegah dan menanggulangi pencemaran dan kerusakan lingkungan hidup". Kepala Daerah menerapkan Sanksi administratif kepada produsen atau penanggung jawab usaha jika dalam pengawasan ditemukan pelanggaran terhadap ketentuan dalam perizinan, sebagaimana di atur dalam Pasal 28 ayat (1) Perda Kabupaten Indramayu Nomor 9 Tahun 2012, sanksi Adminsitratif yang di terapkan dalam bentuk teguran tertulis, paksaan pemerintah, pembekuan izin, atau pencabutan izin (Azwar, 1990). 
Beberapa permasalahan yang timbul adalah tidak berjalannya pengawasan rutin yang merupakan kewajiban dari para pemberi izin. Selain itu lemahnya pendokumentasian informasi dan data serta koordinasi dalam melakukan pengawasan juga menjadi salah satu penyebab. Dalam hal penegakan hukum, tidak konsistennya penjatuhan sanksi administratif kepada pelaku usaha dan/atau kegiatan yang tidak taat menjadi permasalahan lainnya seperti adanya pelanggaran yang cukup berat dan ditindak lanjuti dengan pembinaan, bukan pemberian sanksi, kelonggaran dalam pelaksanaan sanksi, hingga adanya penjatuhan sanksi administratif teguran tertulis yang berulang berkali-kali terhadap suatu pelanggaran tanpa adanya peningkatan. Penegakan hukum lingkungan merupakan suatu hal yang patut dilakukan oleh pemerintah untuk mengatasi masalah lingkungan hidup dalam rangka perlindungan terhadap lingkungan hidup. Upaya tersebut penting dilakukan melalui penegakan hukum untuk mencegah dan menanggulangi pencemaran dan kerusakan lingkungan, baik disebabkan oleh masyarakat maupun pelaku usaha. Perlindungan hukum terhadap lingkungan hidup harus didukung pula oleh instrumen hukum yang baik, peraturan perundang-undangan maupun instrumen hukumnya, serta didukung pula oleh peningkatan kesadaran hukum masyarakat (Soekanto, 1983).

Sebagaimana dijelaskan bahwa peraturan perundang-undangan baik undang-undang maupun perda mengatur cukup jelas tentang kesehatan lingkungan terutama tentang air, namun melihat pada semua ketentua di dalam undang-undang tersebut tidak ada satupun pasal yang mengatur tentang penyelesaian persoalan perlindungan hukum dan jaminan hak atas air bersih baik secara litigasi maupun non-litigasi, ketika misalkan perbuatan seseorang yang 
menimbulkan gangguan kesehatan terhadap orang lain akibat pencemaran air. Meskipun undang-undang ini mengatur dan mempertajam mengenai hak seseorang untuk mendapatkan lingkungan yang sehat (hak atas air bersih) bagi pencapaian derajat kesehatan, namun di dalam undang-undang ini terutama terkait dengan pengaturan sanksi hukumnya, tidak mengatur sanksi hukum bagi seseorang yang melanggar hak orang lain untuk mendapatkan kualitas air bersih dan sehat bagi pencapaian derajat kesehatan manusia. Upaya pemulihan lingkungan hidup dapat dipenuhi dalam kerangka penanganan sengketa lingkungan melalui penegakkan hukum lingkungan. Penegakan hokum lingkungan merupakan bagian dari siklus pengaturan (regulatory chain) perencanaan kebijakan (policy planning) tentang lingkungan. Penegakan hukum lingkungan di Indonesia mencakup penataan dan penindakan (compliance and enforcement) yang meliputi bidang hokum administrasi negara, bidang hokum perdata dan bidang hokum pidana (Ramadhan, 2018).

Lingkungan yang sehat akan memberikan dampak yang baik terhadap kehidupan manusia serta dapat memberikan kenyamanan bagi dirinya oleh sebab itu perlu disadari bahwa lingkungan merupakan pemegang peranan terpenting bagi kehidupan manusia lingkungan yang terawat maka akan menjamin kwalitas manusia yang sehat namun pada kenyataannya pada saat ini banyak lingkungan yang terabaikan dalam pemeliharaan llingkungan sehingga lingkungan rusak karena ulah manusia karena disebabkan oleh ketidaktahuaan dari manusia. Kebijakan Pemerintah Daerah Kabupaten Indramayu dalam mengatasi kualitas air bersih dibuatnya Perda No. 9 Tahun 2009 tentang Pengelolaan Kualitas Air dan Pengendalian Pencemaran Air. Merupakan upaya tersistematis dan terpadu untuk 
melestarikan fungsi ligkungan hidup dan mencegah terjadinya pencemaran, akan tetapi masih terdapat pencemaran lingkungan hidup berupa pencemaran limbah pada air sungai di Desa Kenanga Kabupaten Indramayu, sehingga upaya penegakan hukum yang dilakukan Pemerintah Daerah dalam mengatasi permasalahan lingkungan hidup, baik secara preventif maupun represif tidak terlepas dari terminologi sistem hukum untuk memahami efektivitas berfungsinya hukum dalam mengubah perilaku manusia agar mempunyai kesadaran hukum dalam rangka melindungi dan melestarikan fungsi lingkungan hidup.

\section{PENUTUP}

Berdasarkan hasil pembahasan yang telah diuraikan dapat disimpulkan. Pertama, pelestarian kualitas air dan pencemaran air yang mengacu pada Peraturan Daerah Kabupaten Indramayu Nomor 9 Tahun 2012 belum maksimal dilakukan. Karena masih ada Masyarakat yang membuang limbah ke sungai yang mengakibatkan air sungai yang tidak dapat di manfaatkan untuk kehidup masyarakat desa. Beberapa faktor yang mempengaruhi implementasi peraturan daerah Kabpaten Indramayu nomor 9 tahun 2012 tentang Pengelolaan Kualitas Air dan Pengendalian Pencemaran Air, meliputi faktor internal dan faktor eksternal. Faktor Internal yang dihadapi yaitu kurangnya sumber daya implementasi yang dimiliki oleh Dinas Lingkungan Hidup dan Kebersihan. Sedangkan faktor eksternal yang dihadapi oleh Dinas Lingkungan Hidup dan Kebersihan yaitu masih rendahnya partisipasi masyarakat untuk ikut serta dalam menjaga kelestarian lingkungan. Kedua, pada Pasal 28 Perda Nomor 9 Tahun 2012 menghendaki penegakan hukum lingkungan merupakan suatu hal yang patut dilakukan oleh pemerintah untuk mengatasi masalah lingkungan hidup dalam rangka perlindungan terhadap lingkungan hidup, penerpan sanksi hukum bagi Produsen Krupuk Home 
Industry Krupuk Desa Kenanga Kecamatan Sindang Kabupaten Indramayu dalam pencemaran Sungai tidak konsistennya penjatuhan sanksi administratif kepada pelaku usaha dan/atau kegiatan yang tidak taat menjadi permasalahan lainnya seperti adanya pelanggaran yang cukup berat dan ditindak lanjuti dengan pembinaan, bukan pemberian sanksi, kelonggaran dalam pelaksanaan sanksi, hingga adanya penjatuhan sanksi administratif teguran tertulis yang berulang berkali-kali terhadap suatu pelanggaran tanpa adanya peningkatan.

Berdasarkan simpulan tersebut, maka penulis memberikan saran. Pertama, lepada Pemerintah Kabupaten Indramayu diperlukannya penegasan sanksi hukum terhadap pihak-pihak yang melakukan pencemaran dan/atau melanggar perizinan agar mereka mendapat efek jera atas perbuatannya, guna mengimplementasikan ketentuan Peraturan Daearah Kabupaten Indramayu Nomor 9 Tahun 2012 tentan Pengelolaan Kualitas Air dan Pengendalian Pencemaran Air. Kedua, kepala Desa Kenanga Kecamatan Sindang Kabupaten Indramayu kepada Kepala Desa Kenanga Kecamatan Sindang Kabupaten Indramayu agar turut serta berperan dalam mengatasi permasalahan pencemaran air yang ada di lakuka penduduk Desa Kenanga. 


\section{DAFTAR PUSTAKA}

\section{Buku}

Azwar, A. (1990). Pengantar Ilmu Kesehatan Lingkungan. Yayasan Mutiara.

Friedman, M. L. (1975). The Legal System, A Social Science Prespective. Russel Sage Foundation.

Keraf, S. (2010). Etika Lingkungan Hidup. PT. Kompas.

Muchtar, M., \& Naroida, A. K. (2016). Hukum Kesehatan Lingkungan: Kajian Teoritis Dan Perkembangan Pemikiran (1st ed.). PT. Pustaka Baru Press.

Muhamat, E. (2008). Hukum Lingkungan Dalam Sistem Kebijaksanaan Pembangunan Lingkungan Hidup. PT. Refika Aditama.

Rahardjo, S. (1991). Ilmu Hukum. PT. Citra Aditya Bakti.

Santosa, M. A. (1997). Penerapan Asas Tanggung Jawab Mutlak (Strict Liability) di Bidang Lingkungan Hidup. Indonesian Center of Environmental Law (ICEL).

Soekanto, S. (1983). Faktor-faktor yang Mempengaruhi Penegakan Hukum. PT. Rajawali Press.

\section{Artikel Jurnal}

Arnop, O. (2019). Kajian Evaluasi Mutu Sungai Nelas dengan Metode Storet dan Indeks Pencemaran. Jurnal Penelitian Pengelolaan Sumberdaya Alam Dan Lingkungan, 8(1).

Belladona, M. (2017). Jurnal Analisis Tingkat Pencemaran Sungai Akibat Limbah Industri Karet di Kabupaten Bengkulu Tengah. Jurnal Biogenesis, 1(2).

Herlina, N. (2015). Permasalahan Lingkungan Hidup dan Penegakan Hukum Lingkungan di Indonesia. Jurnal Ilmiah Galuh Justisi, 3(2).

Ilyas. (2018). Manajemen Limbah Home Industri Konveksi Pengusha Muslim Sebagai Upaya Menambah Pendapatan Ekonomi Keluarga Di Desa Tingkir Lor Kec. Tingkir Kota Salatiga. Jurnal Penelitian Pendidikan, 33(2).

Naslilmuna, M. (2018). Analisis Kualitas Air Tanah Dan Pola Konsumsi Air Masyrakat Sekitar Industri Kertas PT. Jaya Kertas Kecamatan Kertosono Kabupaten Nganjuk. 
", Jurnal GeoEco, 4(1), 51-58.

Pratama, A. (2020). Penegakan Hukum terhadap Pencemaran Lingkungan Limbah Industri di Perairan Karawang, Jawa Barat. Journal of Multidisciplinary Studies, $11(01)$.

Ramadhan, N. I. (2018). Studi Status Lingkungan Hidup Perkotaan Berkelanjutan dengan Metode Analisis Pressure State and Response di Kota Surakarta. Jurnal Arsitektur Dan Perencanaan, 1(2), 207-222.

Wahyuningsih, H. (2018). Studi Status Lingkungan Hidup Perkotaan Berkelanjutan dengan Metode Analisis PressureState and Response di Kota Surakarta. Jurnal Arsitektur Dan Perencanaan Universitas 'Aisyiyah (UNISA) Yogyakarta, 1(2), 207-222.

Walid, A. (2020). Analisis Kualitas Air Sungai Kikim Di Kecamatan Kikim Timur Kabupaten Lahat. Jurnal Ilmiah Ilmu Dasar Dan Lingkungan Hidup, 20(2), 52-57.

Yuda, O. O. (2018). Implementasi Kebijakan Pengendalian Pencemaran Limbah Cair Hotel di Kota Yogyakarta Tahun 2017. Jurnal Administrasi Publik, Desember, $163-171$.

\section{Peraturan Perundang-Undangan}

Sekretaris Negara Republik Indonesia. 2001. Peraturan Pemerintah Nomor 82 Tahun 2001 Tentang Pengelolaan Kualitas Air dan Pengendalian Pencemaran Air (Lembaran Negara Republik Indonesia Tahun 2001 Nomor 153, Tambahan Lembaran Negara Republik Indonesia Nomor 4161). Jakarta: Menteri Hukum dan Hak Asasi Manusia Republik Indonesia.

Sekretaris Negara Republik Indonesia. 2009. Undang-Undang Negara Republik Indonesia Nomor 32 Tahun 2009 Tentang Perlindungan dan Pengelolaan Lingkungan Hidup. (Lembaran Negara Republik Indonesia Tahun 2009 Nomor 140, Tambahan Lembaran Negara Republik Indonesia Nomor 5059). Jakarta: Menteri Hukum dan Hak Asasi Manusia Republik Indonesia.

Sekretaris Daerah Kabupaten Indramayu. 2012. Peraturan Daerah Kabupaten Indramayu Nomor 9 Tahun 2012 Tentang Pengelolaan Kualitas Air Dan Pengendalian Pencemaran Air (Lembaran Daerah Kabupaten Indramayu Tahun 2012 Nomor 9): Indramayu: Sekretaris Daerah Kabupaten Indramayu. 